\title{
The effect of doping on the electronic structure and optical properties of silicon biprismanes: DFT and TD-DFT studies
}

\author{
M. A. Salem ${ }^{1,4}$, M. A. Gimaldinova ${ }^{1,2}$, A. I. Kochaev ${ }^{3}$, M. M. Maslov ${ }^{\dagger, 1,2}$ \\ †Mike.Maslov@gmail.com \\ ${ }^{1}$ National Research Nuclear University MEPhI, 31 Kashirskoe shosse, Moscow, 115409, Russia \\ ${ }^{2}$ Research Institute for the Development of Scientific and Educational Potential of Youth, \\ 14/55 Aviatorov St., Moscow, 119620, Russia \\ ${ }^{3}$ Ulyanovsk State University, 42 Leo Tolstoy St., Ulyanovsk 432017, Russia \\ ${ }^{4}$ Zagazig University, Zagazig, 44519, Sharkia, Egypt
}

\begin{abstract}
We present the results of a study of three-layered silicon biprismanes doped with methyl radicals and fluorine atoms by means of the density functional theory. Pentagonal, hexagonal, heptagonal, and octagonal doped systems were simulated in this study. We found that larger biprismanes demonstrate weaker interaction with dopants because they are less strained, and their surfaces are "flatter". The weakening of interaction manifests itself by elongation of bond lengths between the silicon cage and the attached radicals. However, the energy gain/loss due to the reaction of substitutional doping is practically independent of the size of the system. The calculated partial Mulliken charges of fluorine atoms are about -0.3 of elementary charges. The corresponding value for methyl radicals is approximately three times smaller. HOMO-LUMO gaps of doped biprismanes demonstrate oscillations with increasing biprismane diameter with a general downward trend. The value of the gaps of the doped biprismanes is in the range from 2 to $3 \mathrm{eV}$ and slightly differs from the gaps of the pristine biprismanes. The optical properties and excited states of doped biprismanes were calculated using the time-dependent density functional theory. Ultra-violet and visible spectra were determined for all considered systems. The absorption frequencies slightly depend on the radical type and the size of the system. However, the presence of radicals results in significant changes in the relative adsorption intensities of biprismanes with different shapes. We found that doping with methyl radicals and fluorine provided prevalent adsorption intensities of octagonal and hexagonal biprismanes, respectively. The observed effect can be used for optical detection of biprismanes with specific shapes or diameters in their mixture with other silicon structures.
\end{abstract}

Keywords: density functional theory, prismane, silaprismane, biprismane, HOMO-LUMO gap, optical spectra.

УДК: 539.196 .5

\section{Влияние допирования на электронную структуру и оптические свойства кремниевых бипризманов: DFT и TD-DFT анализ}

\author{
Салем М. А. ${ }^{1,4}$, Гимальдинова М. А. ${ }^{1,2}$, Кочаев А.И. ${ }^{3}$, Маслов М. М. ${ }^{\dagger, 1,2}$ \\ ${ }^{1}$ Национальный исследовательский ядерный университет «МИФИ», Каширское ш., 31, Москва, 115409, Россия \\ ${ }^{2}$ Научно-исследовательский институт проблем развития научно-образовательного потенциала молодёжи, \\ ул. Авиаторов, 14/55, Москва, 119620, Россия \\ ${ }^{3}$ Ульяновский государственный университет, ул. Л. Толстого, 42, Ульяновск, 432017, Россия \\ ${ }^{4}$ Университет Загазига, Загазиг, 44519, Шаркия, Египет
}

В настоящей работе мы представляем результаты анализа трехслойных кремниевых бипризманов, легированных метильными группами и атомами фтора с использованием теории функционала плотности. Мы рассмотрели допированные системы, образованные пяти-, шести-, семи- и восьмичленными кремниевыми кольцами. Установлено, что более крупные бипризманы слабее взаимодействуют с легирующими добавками, из-за меньшей напряженности 
каркаса, то есть их поверхности являются «более плоскими». Ослабление взаимодействия проявляется в том числе в удлинении ковалентных связей между кремниевым каркасом и присоединенными радикалами. Однако выигрыш/потеря энергии в результате реакции замещающего легирования практически не зависит от эффективного размера системы. Расчетные парциальные малликеновские заряды атомов фтора отрицательны и составляют -0.3 элементарных зарядов. Соответствующее значение для метиленовых групп примерно в три раза меньше. Щели HOMO-LUMO легированных бипризманов испытывают колебания с увеличением их диаметра с общей тенденцией к уменьшению. Величина щели допированных бипризманов находится в диапазоне от 2 до 3 эВ и незначительно отличается от соответствующих значений для незамещенных систем. Оптические свойства и возбужденные состояния допированных бипризманов рассчитывались с использованием нестационарной теории функционала плотности (TD-DFT). Для всех рассмотренных систем мы определили ультрафиолетовый и видимый спектры. Установлено, что частоты поглощения слабо зависят от типа радикала и эффективного размера системы. Однако присутствие радикалов приводит к значительным изменениям относительных интенсивностей спектров поглощения бипризманов различной формы. Мы обнаружили, что допирование метильными радикалами и атомами фтора обеспечивает преобладающую интенсивность спектров поглощения окта- и гекса-бипризманов соответственно. Наблюдаемый эффект может быть использован для оптического обнаружения бипризманов с конкретной структурой или диаметром в смеси с другими кремниевыми системами.

Ключевые слова: теория функционала плотности, призман, силапризман, бипризман, HOMO-LUMO щель, оптические спектры.

\section{Introduction}

Silicon polyprismanes (SPP) [1] are a novel class of strained silicon nanoclusters. Despite the existence of other systems with a highly-strained framework, such as fullerites $[2,3]$ or curved nanotubes $[4,5]$, silaprismanes have a special silicon morphology that affects their physicochemical characteristics. The smallest SPPs consist of two conjugated polygonal rings, located in parallel planes and bound with each other by covalent bonds (the simplest example is the cubic-shaped silicon cubane $\mathrm{Si}_{8} \mathrm{H}_{8}$ [6]). Biprismanes are SPPs consisting of three polygonal rings. Long SPPs contain more rings, and their number is not restricted. In the bulk limit, SPPs are elongated quasi-1D nanostructures with polygonal cross-sections and $s p^{3}$ type of hybridization. Note that the elementary representatives of the silicon polyprismanes, as well as their carbon analogs, have already been synthesized [7-10].

The unusual form of SPPs results in their unique electronic structure. They demonstrate a cylinder type of aromaticity, which provides their stability [11]. Also, bulk SPPs possess metallic conductivity [12], not typical for $s p^{3}$-hybridized compounds. One-dimensional vibrations of a foreign atom trapped inside the SPP can provide both terahertz and gigahertz emissions [13].

Besides interest to SPPs itself, they are considered as promising building blocks for novel materials with more complicated structures. Carbon analogous of SPPs [14] are embedded into some new diamond-like allotropes $[15,16]$ and form stable $1 \mathrm{D}[17,18], 2 \mathrm{D}[19,20]$ and $3 \mathrm{D}[18,21]$ structures. Similarly, SPPs can produce a family of silicon clusters and crystal forms with different dimensionalities.

Although the Si-Si single bond is somewhat weaker than the similar C-C bond [22], SPPs are quite robust compounds. It was shown that substituted $\mathrm{Si}$ atoms included in prismatic carbon cages increase the stability of the hybrid carbonsilicon prismatic cluster [23]. SPPs are more stable than carbon analogous [24] and keep their identities even at rather high temperatures $[25,26]$. For these reasons, manipulations with SPPs are preferable from the practical point of view in comparison with carbon polyprismanes.
Doping is the traditional way to modify the characteristics of any material for chosen applications. In SPPs, all atoms are tetra-coordinated, i.e., all four bonds of each silicon atom are totally saturated. Therefore, only two types of doping are possible: trapping of foreign atoms inside the SPP with the formation of endohedral "host-guest" complexes and substitutional doping of prismane's ends. Although endohedral SPPs can be spontaneously formed in the plasma reactor [27], guest atoms decrease the stability of the system [28]. Therefore, we restrict our study by the case of ends doping. In this case, the hydrogen atoms passivating the system are replaced by any other atoms or radicals. In the present Letter, we study the doping effect on the electronic properties and optical spectra of SPPs via the $a b$ initio density functional theory (DFT) and time-dependent density functional theory (TD-DFT) calculations. The concentration of dopants strongly depends on the number of rings in the SPP. For the case of infinitely long SPPs, the fraction of end atoms that can be doped is negligible. In the opposite case of the simplest SPPs, consisting of only two rings, this fraction is equal to unity. Here we consider silicon biprismanes as the elementary members of the SPP family, which include both terminal and internal silicon rings.

\section{Materials and methods}

We considered four silicon biprismanes $\mathrm{Si}_{3 n} \mathrm{H}_{2 n}(n=5 \div 8)$, consisting of three polygonal rings. In contrast to other polyaromatic silicon structures (for example, silicene), all rings in biprismanes are "flat" (see their atomic structures in Fig. 1). In the doped biprismanes, all hydrogen atoms are substituted by radicals $\mathrm{R}$. We restricted our study by two ordinary radicals: $\mathrm{R}=\mathrm{F}$ that is the most electronegative element, and $\mathrm{R}=\mathrm{CH}_{3}$ that was previously considered as a dopant to the hydrocarbon cubane [29].

We applied GAMESS software [30] for all DFT and TD-DFT investigations described below. Geometry optimization, energy, and electronic structure calculations were performed with hybrid B3LYP functional $[31,32]$ with the 6-31G(d) electronic basis set [33]. Time-dependent DFT 


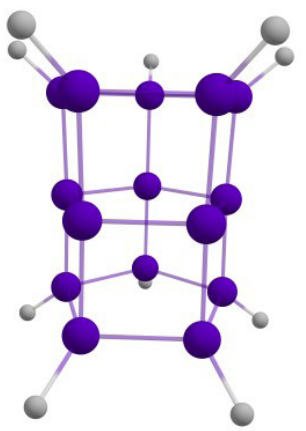

a

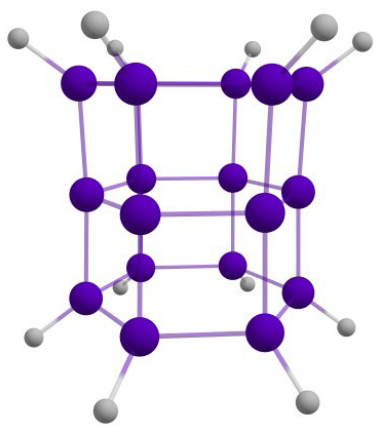

$\mathrm{b}$

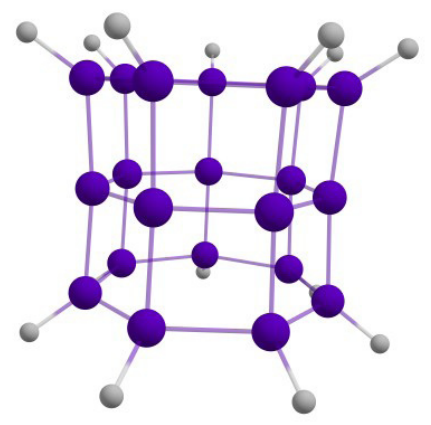

$\mathrm{c}$

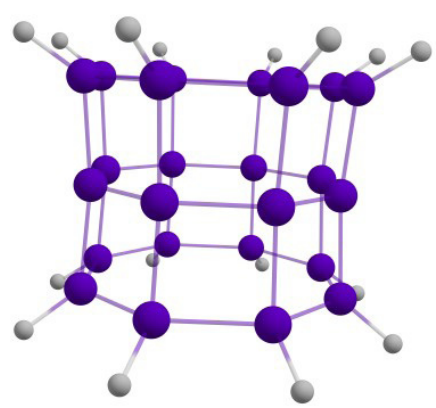

d

Fig. 1. (Color online) Atomic structures of pristine silicon biprismanes $\mathrm{Si}_{3 n} \mathrm{H}_{2 n}$ for $n=5$ (a), 6 (b), 7 (c) and 8 (d).

calculations were done using CAM-B3LYP functional with the same basis set. The latter functional provides an account of long-range electronic interactions, which are essential for excited states. Twenty excited states were considered.

The energy of substitution Esub for each radical $\mathrm{R}\left(\mathrm{R}=\mathrm{CH}_{3}, \mathrm{~F}\right)$ is defined as

$$
E_{\text {sub }}=\frac{1}{2 n}\left\{E\left(\mathrm{Si}_{3 n} \mathrm{R}_{2 n}\right)+2 n E(\mathrm{H})-E\left(\mathrm{Si}_{3 n} \mathrm{H}_{2 n}\right)-2 n E(\mathrm{R})\right\},
$$

where $E\left(\mathrm{Si}_{3 n} \mathrm{R}_{2 n}\right)$ and $E\left(\mathrm{Si}_{3 n} \mathrm{H}_{2 n}\right)$ are the total energies of doped and pristine biprismanes, respectively; $E(\mathrm{H})$ and $E(\mathrm{R})$ are the total energies of the radical and hydrogen atom; $2 n$ is the total number of the attached radicals. The energy of substitution reaction $E_{\mathrm{r}}$ is calculated as the energy difference between products and reactants of the hypothetical reaction

$$
\mathrm{Si}_{3 n} \mathrm{H}_{2 n}+n \mathrm{R}_{2} \rightarrow \mathrm{Si}_{3 n} \mathrm{R}_{2 n}+n \mathrm{H}_{2} .
$$

For obtaining the value of $E_{\mathrm{r}}$ per one radical R, this energy difference is divided by the number of attached radicals $\mathrm{R}$ :

$$
E_{\mathrm{r}}=\frac{1}{2 n}\left\{E\left(\mathrm{Si}_{3 n} \mathrm{R}_{2 n}\right)+n E\left(\mathrm{H}_{2}\right)-E\left(\mathrm{Si}_{3 n} \mathrm{H}_{2 n}\right)-n E\left(\mathrm{R}_{2}\right)\right\} \text {. }
$$

Energy value $E_{\mathrm{r}}$ indicates the energy gain $\left(E_{\mathrm{r}}<0\right)$ or loss $\left(E_{\mathrm{r}}>0\right)$ due to the passing of the reaction. The HOMO-LUMO gap is defined as the energy gap between the highest occupied molecular orbital and the lowest unoccupied molecular orbital.

\section{Results and discussions}

The calculated substitutional energies, reaction energies, partial atomic charges, HOMO-LUMO gaps, and bond lengths between radicals and biprismanes are collected in Table 1. One can see that $E_{\text {sub }}$ and $E_{\mathrm{r}}$ values are positive for doping with methyl radicals and negative for doping with fluorine. This indicates that the fluorination of biprismanes is energetically feasible and can pass spontaneously. Such a result is predictable based on the well-known strength of Si-F bonds, which manifests itself in a very negative enthalpy of formation of $\mathrm{SiF}_{4}$ and similar compounds. For $\mathrm{CH}_{3}$-doped biprismanes, both $E_{\text {sub }}$ and $E_{\mathrm{r}}$ increase with $n$, whereas F-doped biprismanes demonstrate oscillation behavior of these energies on $n$. However, variations of $E_{\text {sub }}$ and $E_{\mathrm{r}}$ have amplitudes of tens of $\mathrm{meV}$ that is comparable with the energy of thermal vibrations and close to the accuracy of the applied
Table 1. Substitutional energies $E_{\text {sub }}$, reaction energies $E$, total Mulliken charges $q_{\mathrm{M}}$, the HOMO-LUMO gaps $E_{\mathrm{g}}$, and interatomic distances $l_{\mathrm{Si}-\mathrm{R}}$ between $\mathrm{Si}$ atom and radical $\mathrm{R}$ for the doped silicon biprismanes $\mathrm{Si}_{3 n} \mathrm{R}_{2 n}$.

\begin{tabular}{|c|c|c|c|c|c|}
\hline$n$ & $E_{\text {sub }}, \mathrm{eV}$ & $E_{\mathrm{r}}, \mathrm{eV}$ & $q_{\mathrm{M}} / \mathrm{e} \mid$ & $E_{\mathrm{g}}, \mathrm{eV}$ & $l_{\mathrm{si}-\mathrm{R}}, \AA$ \\
\hline \multicolumn{6}{|c|}{$\mathrm{R}=\mathrm{CH}_{3}$} \\
\hline 5 & 0.314 & 0.059 & -0.106 & 2.294 & 1.917 \\
\hline 6 & 0.321 & 0.066 & -0.117 & 2.468 & 1.919 \\
\hline 7 & 0.324 & 0.070 & -0.126 & 2.063 & 1.920 \\
\hline 8 & 0.333 & 0.078 & -0.131 & 2.215 & 1.922 \\
\hline \multicolumn{7}{|c|}{$\mathrm{R}=\mathrm{F}$} \\
\hline 5 & -2.341 & -3.786 & -0.303 & 2.795 & 1.632 \\
\hline 6 & -2.332 & -3.778 & -0.302 & 2.697 & 1.633 \\
\hline 7 & -2.356 & -3.802 & -0.301 & 2.503 & 1.634 \\
\hline 8 & -2.348 & -3.794 & -0.300 & 2.568 & 1.634 \\
\hline
\end{tabular}

density functional method. So, the diameter of biprismane slightly affects the energy gain from the doping.

The Si-R bond length increases with $n$ for both regarded radicals. This fact indicates a weakening of the chemical bond between the biprismane skeleton and the doping radical. Such behavior was expected because biprismanes with larger diameters are less strained, and their surfaces are flatter. It is well known that the flatter surface is less reactive. For example, a similar effect was experimentally observed for graphene [34]. However, silicon cages with larger diameters interact slighter not only with radicals but also with hydrogen atoms approximately in the same way. Therefore, the elongations of Si-R bonds with $n$ do not result in a change in the $E_{\text {sub }}$ and $E_{\mathrm{r}}$ values.

Partial Mulliken charges of different radicals $q_{\mathrm{M}}$ possess different dependences on $n$. The absolute value of $q_{\mathrm{M}}$ increases with $n$ for the methyl-doped systems and remains unchanged for the fluorine-doped systems. In both cases, $q_{\mathrm{M}}$ is negative because the electronegativity of $\mathrm{Si}$ is lower than the corresponding value for carbon and fluorine. The higher absolute value of $q_{\mathrm{M}}$ for fluorine-doped systems is a consequence of the higher electronegativity of fluorine.

The HOMO-LUMO gaps demonstrate oscillation behavior during increasing of biprismane diameter with a general downward trend. Their values are in the ranges $2 \div 2.5 \mathrm{eV}$ and $2.5 \div 2.8 \mathrm{eV}$ for methyl- and fluorine-doped biprismanes, respectively. It should be noted that the 
HOMO-LUMO gaps of pristine biprismanes are close to these values and lie in the range of $2 \div 2.5 \mathrm{eV}$ [1]. The visualization of HOMO and LUMO molecular orbitals can be found in Supplementary Material. So considered radicals cannot be used for decreasing the HOMO-LUMO gaps of biprismanes. Other radicals or their combinations should be tried for this purpose.

The optical ultra-violet and visible spectra of doped biprismanes are presented in Fig. 2. We found that the maximal adsorption intensity was determined by the diameter of the system. The dependence of the optimal adsorption frequency on $n$ is complicated and non-monotonic. As a rule, increasing the system size results in a red shift in its spectrum. Remarkably that different doping radicals provide the highest intensity for biprismanes with varying values of $n$. So, for fluorine-doped systems, hexagon biprismanes possess a prevalent optical response. In contrast, among the methyl-doped systems, the most optically active are octagonal biprismanes. This effect can be used to distinguish biprismanes with a certain $n$ from their mixtures with other silicon structures. Other radicals can probably activate biprismanes with different values of $n$.
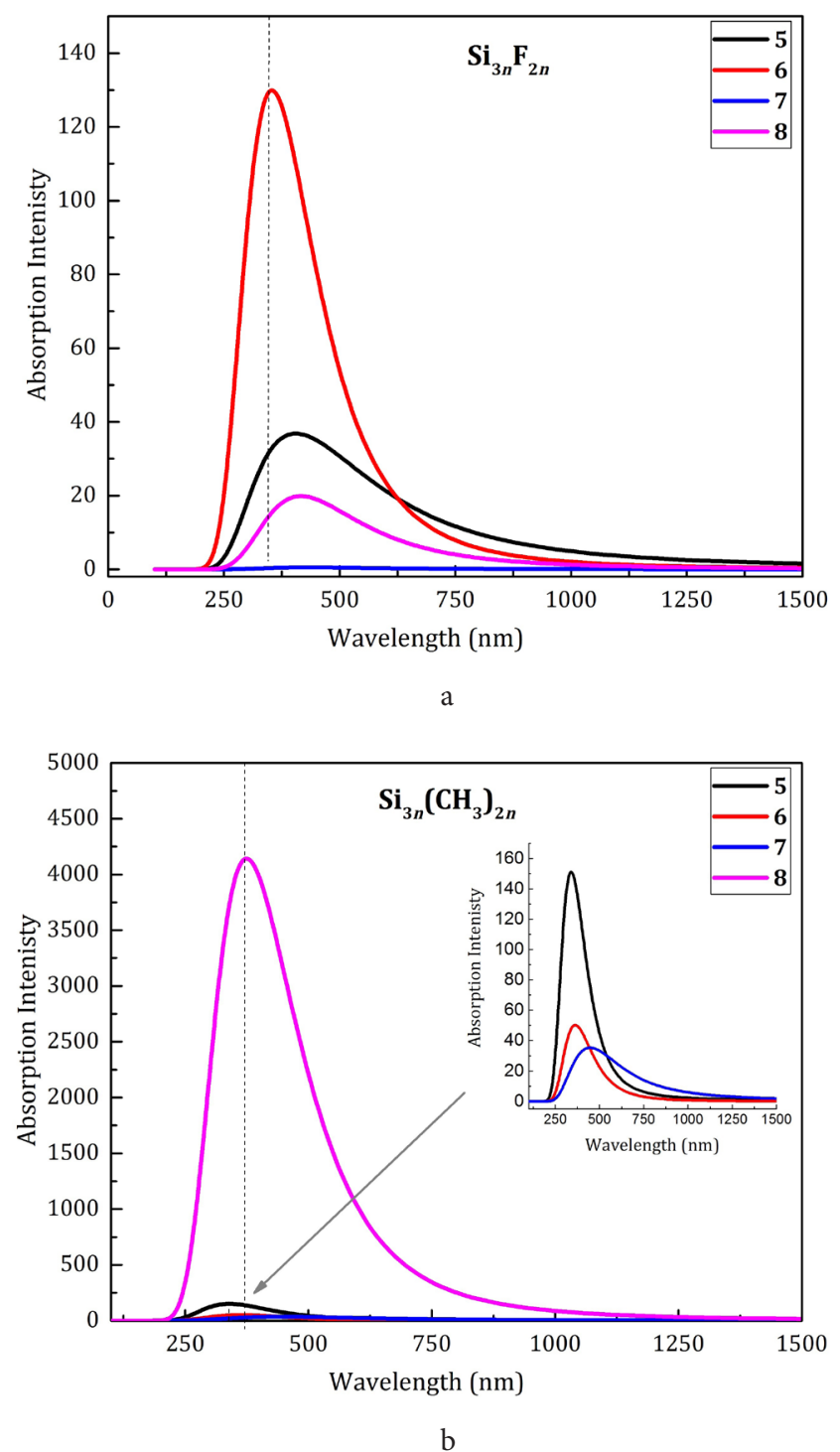

Fig. 2. (Color online) UV-Vis spectra of silicon biprismanes $\mathrm{Si}_{3 n} \mathrm{R}_{2 n}$ $(n=5 \div 8)$ doped with fluorine (a) and methyl radicals (b).

\section{Conclusions}

Doping is a very powerful tool for tuning the properties of nanostructures and other materials. The utility of any compound is primarily determined by its interaction with dopants. From this point of view, SPPs are rather inconvenient materials, because they are chemically inert and can not adsorb functional groups on their surfaces. Thus, the substitution of hydrogen atoms at the ends of SPPs by any other radicals is the most feasible way of doping them. In contrast to the formation of host-guest compounds by encapsulation inside the silicon framework or substitution of the silicon atoms of the latter, the edge doping conserves the form of SPP and keeps them stable. In the presented study, we demonstrate the ability of two ordinary radicals (methyl radical and fluorine atom) to modify the electronic structure and optical spectra of biprismanes. Further extensive calculations involving more radicals can provide broad variations in the SPP characteristics and their tuning. We hope that our research will stimulate such studies in the future.

Supplementary Materials. The online version of this paper contains supplementary material available free of charge at the journal's Web site (lettersonmaterials.com).

Acknowledgments. The presented study was performed with the financial support of the Russian Science Foundation (Grant No. 18-72-00183). Mikhail Maslov thanks the DSEPY-RI for the provided computing resources and comprehensive support of the presented study.

\section{References}

1. M.A. Gimaldinova, K.P. Katin, M.A. Salem, M. M. Maslov. Lett. Mater. 8 (4), 454 (2018). Crossref

2. V. Blank, M. Popov, S. Buga, V. Davydov, V.N. Denisov, A. N. Ivlev, B. N. Marvin, V. Agafonov, R. Ceolin, H. Szwarc, A. Rassat. Physics Letters A. 188 (3), 281 (1994). Crossref

3. V.D. Blank, S. G. Buga, G. A. Dubitsky, N. R. Serebryanaya, M. Yu. Popov, B. Sundqvist. Carbon. 36 (4), 319 (1998). Crossref

4. G.-L. She, F.-G. Yuan, B. Karami, Y.-R. Ren, W.-S. Xiao. International Journal of Engineering Science. 135, 58 (2019). Crossref

5. Z. Ma, J. Yang, L. Wang, L. Shi, P. Li, G. Chen, C. Miao, C. Mei. Journal of Alloys and Compounds. 745, 688 (2018). Crossref

6. Ç. Kılıç, T. Yildirim, H. Mehrez, S. Ciraci. J. Phys. Chem. A. 104 (12), 2724 (2000). Crossref

7. T. J. Katz, N. Acton. J. Am. Chem. Soc. 95 (8), 2738 (1973). Crossref

8. P.E. Eaton, Y.S. Or, S. J. Branca. J. Am. Chem. Soc. 103 (8), 2134 (1981). $\underline{\text { Crossref }}$

9. H. Matsumoto, K. Higuchi, S. Kyushin, M. Goto. Angewandte Chemie International Edition in English. 31 (10), 1354 (1992). $\underline{\text { Crossref }}$

10. N. Koshida, N. Matsumoto. Materials Science and Engineering: R: Reports. 40 (5), 169 (2003). Crossref 
11. L. V. Duong, E. Matito, M. Solà, H. Behzadi, M. T. Nguyen, M.J. Momeni. Phys. Chem. Chem. Phys. 20, 23467 (2018). Crossref

12. K.P. Katin, K.S. Grishakov, M.A. Gimaldinova, M.M. Maslov. Comp. Mat. Sci. 174, 109480 (2020). Crossref

13. H. Vach. Phys. Rev. Lett. 112 (19), 197401 (2014). $\underline{\text { Crossref }}$

14. K.P. Katin, S.A. Shostachenko, A.I. Avkhadieva, M. M. Maslov. Adv. Phys. Chem. 2015, 506894 (2015). Crossref

15. L. K. Rysaeva, D. S. Lisovenko, V.A. Gorodtsov, J.A. Baimova. Comp. Mat. Sci. 172, 109355 (2020). Crossref

16. L.K. Rysaeva, J.A. Baimova, S.V. Dmitriev, D.S. Lisovenko, V.A. Gorodtsov, A.I. Rudskoy. Diamond and Related Materials. 97, 107411 (2019). $\underline{\text { Crossref }}$

17. K. P. Katin, M. M. Maslov. Adv. Cond. Matt. Phys. 2015, 754873 (2015). Crossref

18. H.-T. Huang, L. Zhu, M.D. Ward, T. Wang, B. Chen, B. L. Chaloux, Q. Wang, A. Biswas, J.L. Gray, B. Kuei, G.D. Cody, A. Epshteyn, V.H. Crespi, J. V. Badding, T. A. Strobel. J. Am. Chem. Soc. (2020). Crossref

19. M. M. Maslov, K. P. Katin, A. I. Avkhadieva, A. I. Podlivaev. Russ. J. Phys. Chem. B. 8 (2), 152 (2014). Crossref

20. L. Zhou, G. Zhang, F. Xiu, S. Xia, L. Yu. RSC Advances. 10 (15), 8618 (2020). Crossref

21. K. Flanagan, S. S. R. Bernhard, S. Plunkett, M. O. Senge. Chemistry. A European Journal. 25 (28), 6941 (2019). Crossref

22. B. Huang, L. Zhuang, L. Xiao, J. Lu. Chem. Sci. 4 (2), 606 (2013). Crossref
23. A. Equbal, S. Srinivasan, N. Sathyamurthy. J. Chem. Sci. 129 (7), 911 (2017). Crossref

24. M.M. Maslov, K.S. Grishakov, M.A. Gimaldinova, K.P. Katin. Fullerenes, Nanotubes and Carbon Nanostructures. 28, 97 (2019). Crossref

25. K. P. Katin, M. M. Maslov. Molecular Simulation. 44 (9), 703 (2018). Crossref

26. S. A. Shostachenko, M.M. Maslov, V.S. Prudkovskii, K. P. Katin. Phys. Sol. State. 57 (5), 1023 (2015). Crossref

27. H. Vach. Chem. Phys. Lett. 614, 199 (2014). Crossref

28. K. P. Katin, M. B. Javan, M. M. Maslov, A. Soltani. Chem. Phys. 487, 59 (2017). Crossref

29. K.P. Katin, V.S. Prudkovskiy, M. M. Maslov. Physica E: Low-Dimensional Systems and Nanostructures. 81, 1 (2016). Crossref

30. M. W. Schmidt, K. K. Baldridge, J. A. Boatz, S. T. Elbert, M.S. Gordon, J.H. Jensen, S. Koseki, N. Matsunaga, K.A. Nguyen, S. Su, T.L. Windus, M. Dupuis, J. A. Montgomery. J. Comp. Chem. 14 (11), 1347 (1993). Crossref

31. A. D. Becke. J. Chem. Phys. 98 (7), 5648 (1993). Crossref

32. C. Lee, W. Yang, R. G. Parr. Phys. Rev. B. 37 (2), 785 (1988). Crossref

33. R. Krishnan, J. S. Binkley, R. Seeger, J. A. Pople. J. Chem. Phys. 72 (1), 650 (1980). Crossref

34. V.S. Prudkovskiy, K.P. Katin, M. M. Maslov, P. Puech, R. Yakimova, G. Deligeorgis. Carbon. 109, 221 (2016). Crossref 